\title{
Temperature Effect of the Theobromine's Electronic and Antioxidant Properties
}

\author{
Aslı Öztürk Kiraz (iD)*1 \\ ${ }^{1}$ Department of Physics, Faculty of Science\&Letters, Pamukkale University, Denizli, 20070, Turkey
}

\begin{abstract}
Theobromine exists in cocoa, which has an antioxidant ingredient. It is also affect our nervous system. For this reason, it's very important to know the properties of the theobromine. Theobromine is an experimentally studied molecule in the health and pharmaceutical fields. However, there are not many studies on theobromine properties in the theoretical field. Here, we show how theobromine electronic and antioxidant properties change with temperature theoretically. The calculations, were done by using Density Functional Theory (DFT), at B3LYP/6-31G(d,p) level. Six different temperature values (263.15 K, $273.15 \mathrm{~K}, 288.15 \mathrm{~K}, 298.15 \mathrm{~K}, 318.15 \mathrm{~K}, 328.15 \mathrm{~K}$ ) were taken into account. Our results presented that the electronic structure of the theobromine didn't change while the antioxidant properties were changed. Theobromine indicated the most antioxidant property at $263.15 \mathrm{~K}$. Therefore, this situation should be taken into consideration in order to benefit more from the antioxidant properties of theobromine in the field of health and pharmaceuticals.
\end{abstract}

\section{ARTICLE HISTORY}

Received: March 28, 2018

Revised: February 22, 2019

Accepted: March 03, 2019

\section{KEYWORDS}

Theobromine,

Antioxidant,

Electronic Properties

\section{INTRODUCTION}

Theobromine is a bitter and inhalant compound got from cacoa seeds with the chemical formula $\mathrm{C}_{7} \mathrm{H}_{8} \mathrm{~N}_{4} \mathrm{O}_{2}$. When someone see or hear word theobromine there is a bromine atom in the structure of it but there is no bromine atom. The root of the word theobromine is Greek, theo means 'God' and bromine means 'food', so theobromine means 'food of God'. In the sixteenth century the consumption of cocoa drink (chocolate) expanded in Europe especially in Spain which started in America. Because of the rich lasting aroma, chocolate was considered as a good nutrition. Conservatively, high antioxidant ingredient of theobromine found in cocoa beans, is being used in medicine and pharmacology. Especially, the methylxanthines in cocoa are remarkable because of their psychoactive effect. Theobromine and caffeine exist in cocoa, affect our psychology and our state of alertness. Theobromine has much more desirable effects than caffeine so that it is a remarkable molecule in cocoa. To understand the physiological effects of the theobromine in cocoa, characteristics of the ingredients need to be examined

*CONTACT: Aslı ÖZTÜRK KIRAZ $\bowtie$ aslio@pau.edu.tr $\equiv$ Department of Physics, Faculty of Science and Arts, Pamukkale University, Denizli, Turkey 
carefully. Besides, the high ingredients of carbohydrates in cocoa goods may take into account further [1].

The amount of adenosine effect on receptors in neurons is related to brain physiology. The impact of theobromine on adenosine in the brain by using blockers of its specific receptors is begin the daily activities quickly. The blockers of adenosine receptors are caffeine and theobromine. The studies in the recent years represented that theobromine has psychoactive actions in humans are much more effective than caffeine [2,3]. Also, the effect of theobromine on blood pressure distinctive than that of caffeine but the reasons for these differs are not retained $[2,4]$.

The basics of experimental and theoretical studies in the literature for the antioxidant activity of compounds are to give a hydrogen atom to free radicals. Especially, quantum chemical calculations for the quantitative structure-antioxidant activity relationship (QSAR) are more economical process than experimental studies [5-14].

The aim of this study was to investigate the electronic properties antioxidant effect of theobromine changing by temperature using quantum chemical calculations. There are five antioxidant mechanisms that explain antioxidant reactions we used are [15-23]:

1) HAT (Hydrogen Atom Transfer) mechanism:

$$
\mathrm{ArOH}+\mathrm{X}^{\bullet} \rightarrow \mathrm{ArO}^{\bullet}+\mathrm{XH}
$$

2) SET (Single Electron Transfer) mechanism:

$$
\mathrm{ArOH}+\mathrm{X}^{\bullet} \rightarrow \mathrm{ArOH}^{\bullet+}+\mathrm{X}^{-}
$$

3) SET-PT (Single-Electron Transfer followed by Proton Transfer):

$$
\begin{aligned}
& \mathrm{ArOH}+\mathrm{X}^{\bullet} \rightarrow \mathrm{ArOH}^{\bullet+}+\mathrm{X}^{-} \\
& \mathrm{ArOH}^{\bullet+} \rightarrow \mathrm{ArO}^{\bullet}+\mathrm{H}^{+}
\end{aligned}
$$

The SET-PT procedure has two steps. The initial step is an antioxidant molecule reacts with the free radical, and a cationic radical form of the antioxidant and an ionic form of the radical occur. In the continuing step the cationic radical form of the antioxidant separates into a radical and proton.

4) SPLET (Sequential Proton Loss Electron Transfer):

$$
\begin{aligned}
& \mathrm{ArOH} \rightarrow \mathrm{ArO}^{-}+\mathrm{H}^{+} \\
& \mathrm{ArO}^{-}+\mathrm{X}^{\bullet}+\mathrm{H}^{+} \rightarrow \mathrm{ArO}^{\bullet}+\mathrm{XH}
\end{aligned}
$$

This procedure has also two steps. The initial step the antioxidant separates into an anionic form and proton, and then ions occurred in the first reaction react with the free radical. In this reaction a radical form of the antioxidant and a neutral molecule occur.

5) TMC (Transition Metals Chelation): Metals in their low oxidation state may generate free radicals according to the Fenton reaction:

$$
\begin{aligned}
& \mathrm{H}_{2} \mathrm{O}_{2}+\mathrm{Mn}^{+} \rightarrow \mathrm{HO}^{-}+\mathrm{HO}^{\bullet}+\mathrm{M}^{(\mathrm{n}+1)^{+}} \\
& \mathrm{ArOH} \rightarrow \mathrm{ArO}^{-}+\mathrm{H}^{+}
\end{aligned}
$$

In this procedure the ability of a molecule to produce the proton is taken into consideration. One of the significant elucidatory of the electronic and antioxidant properties are dispersion of HOMO and LUMO orbitals. The higher HOMO energy is responsible for the rich 
abilities of a molecule to donate a proton. Therefore, the HOMO dispersion exposes which chemical groups in a molecule are freely attacked by free radicals. From the difference between LUMO and HOMO energy we can accomplish about chemical activity of the molecule. The higher $\triangle \mathrm{E}(\mathrm{LUMO}-\mathrm{HOMO})$ is bounded with higher activity of the molecule [24].

\section{MATERIAL and METHODS}

The electronic and thermal properties of the theobromine in gas phase are theoretically examined by means of Density Functional Theory (DFT) using B3LYP method with 6$31 \mathrm{G}(\mathrm{d}, \mathrm{p})$ basis set. All the calculations (optimization of the geometry of mono- and dianions, optimization of the geometry of the radicals and cation radicals presented in Figure 1) were performed by using Gaussian 16. Revision B.01 program [25] and GaussView 6.0.16 [26] was used for the visualization of the structure and simulation.

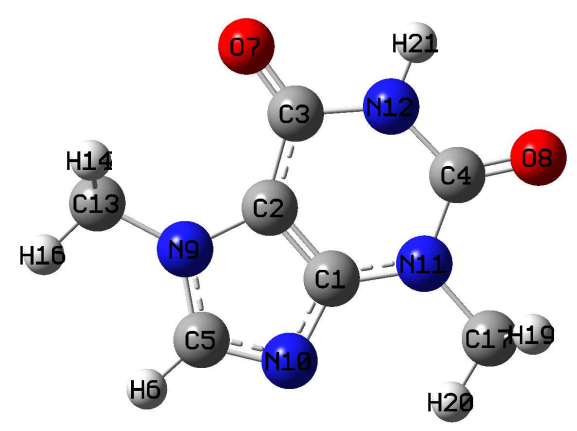

Figure 1. Optimize geometry of Theobromine

Numerical descriptors of the antioxidant mechanism such as Bond Dissociation Enthalpy (BDE), Adiabatic Ionization Potential (AIP), Proton Dissociation Enthalpy (PDE), Proton Affinity (PA), Electron Transfer Enthalpy (ETE), gas phase acidity $\left(\Delta \mathrm{H}_{\text {acidity }}\right)$ defined below have been calculated for the theobromine [15-23].

$$
\mathrm{BDE}=\mathrm{H}_{\mathrm{ArO}} \bullet+\mathrm{H}_{\mathrm{H}}^{\bullet}-\mathrm{H}_{\mathrm{ArOH}}
$$

in which $\mathrm{H}_{\mathrm{ArO}}{ }^{\bullet}$ is the enthalpy of the radical, $\mathrm{H}_{\mathrm{H}}$ is the enthalpy of the $\mathrm{H}$ atom, $\mathrm{H}_{\mathrm{ArOH}}$ is the enthalpy of the compound.

$$
\mathrm{AIP}=\mathrm{H}_{\mathrm{ArOH}}^{\bullet+}-\mathrm{H}_{\mathrm{ArOH}}
$$

here $\mathrm{H}_{\mathrm{ArOH}}{ }^{\bullet+}$ is the enthalpy of cationic radical, $\mathrm{H}_{\mathrm{ArOH}}$ is the enthalpy of the compound.

$$
\mathrm{PDE}=\mathrm{H}_{\mathrm{ArO}}^{\bullet}+\mathrm{H}_{\mathrm{H}}^{+}-\mathrm{H}_{\mathrm{ArOH}}^{\bullet+}
$$

in which $\mathrm{H}_{\mathrm{ArO}}{ }^{\bullet}$ is the enthalpy of the radical, $\mathrm{H}_{\mathrm{H}}{ }^{+}$is the enthalpy of the proton, $\mathrm{H}_{\mathrm{ArOH}}{ }^{\bullet+}$ is the enthalpy of cationic radical.

$$
\mathrm{PA}=\mathrm{H}_{\mathrm{ArO}}^{-}+\mathrm{H}_{\mathrm{H}}^{+}-\mathrm{H}_{\mathrm{ArOH}}
$$

here $\mathrm{H}_{\mathrm{ArO}}{ }^{-}$is the enthalpy of the anion, $\mathrm{H}_{\mathrm{H}}{ }^{+}$is the enthalpy of the proton, $\mathrm{H}_{\mathrm{ArOH}}$ is the enthalpy of the compound.

$$
\mathrm{ETE}=\mathrm{H}_{\mathrm{ArO}} \bullet-\mathrm{H}_{\mathrm{ArO}}
$$


Here $\mathrm{H}_{\mathrm{ArO}} \bullet$ is the enthalpy of the radical, $\mathrm{H}_{\mathrm{ArO}}{ }^{-}$is the enthalpy of the anion.

$$
\Delta \mathrm{H}_{\text {acidity }}=\mathrm{H}_{\mathrm{ArO}}{ }^{-}-\mathrm{H}_{\mathrm{ArOH}}
$$

in which $\mathrm{H}_{\mathrm{ArO}}{ }^{-}$is the enthalpy of the anion, $\mathrm{H}_{\mathrm{ArOH}}$ is the enthalpy of the compound.

\section{RESULTS and DISCUSSION}

\subsection{Antioxidant Properties}

For the HAT mechanism BDE is a significant numerical parameter so it presents the stability of the N-H bond in the theobromine. The lower BDE value identifies better antioxidant property. Our calculations presented in the Table 1 indicated and exhibited Figure 2 that theobromine in the $263.15 \mathrm{~K}$ we selected randomly is the better antioxidant activity selected.

Table 1. Antioxidant Parameters Changing by Temperature.

\begin{tabular}{ccccccc}
\hline $\begin{array}{c}\text { Temperature } \\
(\mathrm{K})\end{array}$ & $\begin{array}{c}\text { BDE } \\
(\text { Hartree })\end{array}$ & $\begin{array}{c}\text { AIP } \\
(\text { Hartree })\end{array}$ & $\begin{array}{c}\text { PDE } \\
\text { (Hartree) }\end{array}$ & $\begin{array}{c}\text { PA } \\
\text { (Hartree.) }\end{array}$ & $\begin{array}{c}\text { ETE } \\
\text { (Hartree.) }\end{array}$ & $\begin{array}{c}\Delta H \\
\text { (Hartree.) }\end{array}$ \\
\hline 263.15 & 0.176603 & 0.283914 & 0.392961 & 0.568707 & 0.108168 & 0.566624 \\
273.15 & 0.176715 & 0.283920 & 0.393068 & 0.568805 & 0.108183 & 0.566642 \\
288.15 & 0.176883 & 0.283929 & 0.393226 & 0.568949 & 0.108206 & 0.566668 \\
298.15 & 0.176995 & 0.283936 & 0.393331 & 0.569441 & 0.107826 & 0.567081 \\
318.15 & 0.177214 & 0.283950 & 0.393537 & 0.569236 & 0.108251 & 0.566717 \\
328.15 & 0.177324 & 0.283958 & 0.393639 & 0.569330 & 0.108267 & 0.566732 \\
\hline
\end{tabular}

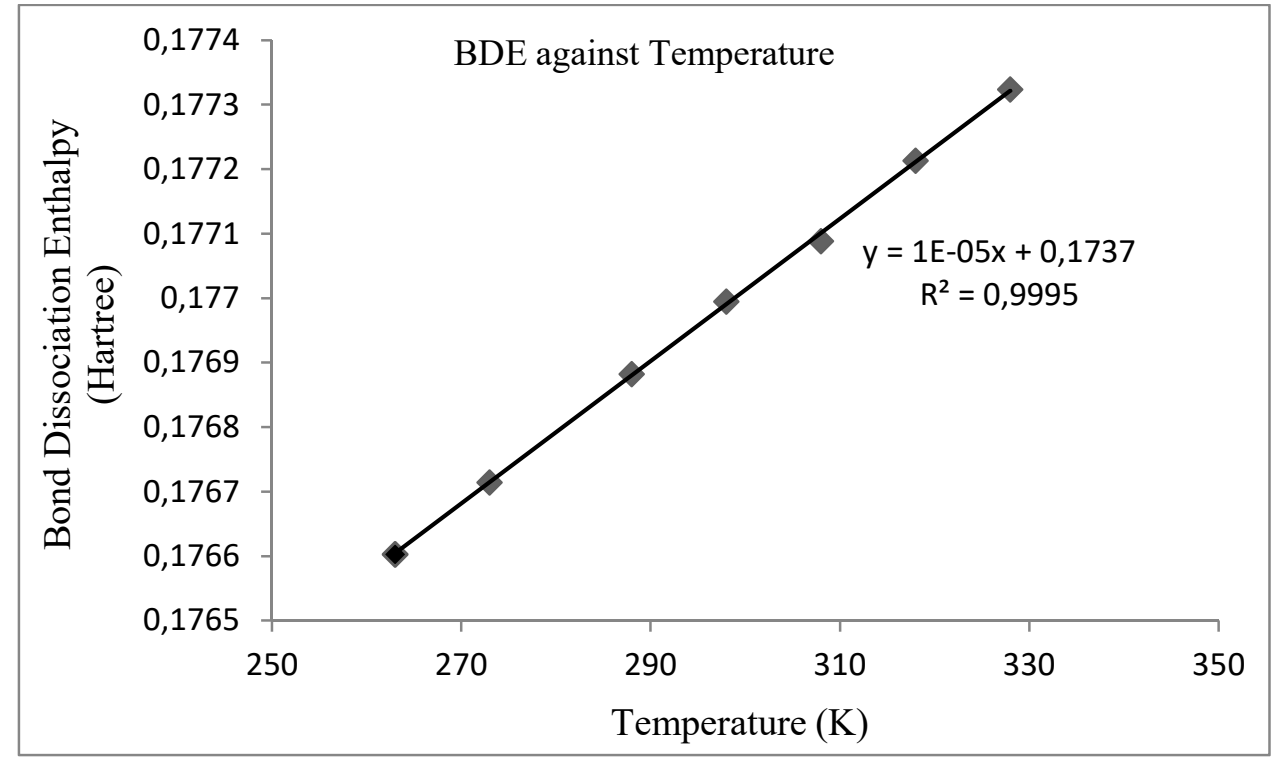

Figure 2. Bond dissociation enthalpy of the theobromine changing by the temperature.

For the SET-PT mechanism AIP is an important parameter because it defines electron forgiving by the antioxidant molecule. The molecule has low AIP parameter exhibited is more sufficient to ionization and shows strong antioxidant property. So from the Table 1 and Figure 3 that theobromine in the $263.15 \mathrm{~K}$ also better antioxidant activity. 


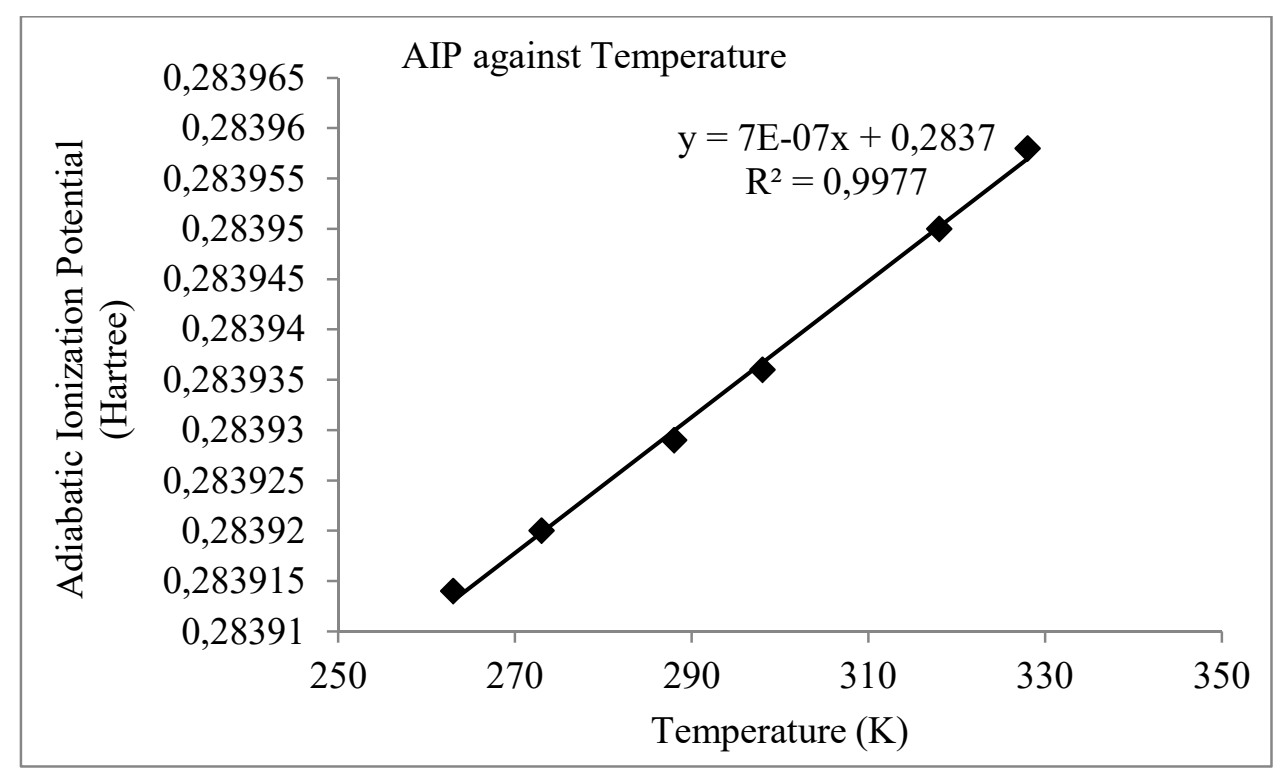

Figure 3. Adiabatic ionization potential theobromine changing by the temperature.

The second step of the SET-PT mechanism the PDE is a significant parameter. The low value of the PDE parameter indicates that SET-PT mechanism is energetically preferred. For the SPLET mechanism PA and ETE are very important parameters. Because of the PA values are higher than BDE and AIP, theobromine molecule doesn't favored SPLET mechanism.

\subsection{Electronic Properties}

For the electronic properties the energies of Highest Occupied Molecular Orbital (HOMO) and Lowest Unoccupied Molecular Orbital (LUMO) are very important parameters. These parameters not explain the antioxidant property directly but describing the electron donating properties they can be connected to antioxidant activity. HOMO-LUMO energy difference represents the chemical reactivity of a molecule. The low HOMO-LUMO gap levels aren't beneficial to hole-injection [27] and evidence of the high probability of the charge transfer in the molecule [28].

In our calculations electronic parameters of the Theobromine didn't turn by the changing the selected randomly temperature. So, here in Figure 4, we use the only $298.15 \mathrm{~K}$ parameters for calculating the electronic parameters and presenting the HOMO-LUMO orbitals. $\mathrm{E}_{\text {HOMO }}$ is an energy of HOMO orbital, ELUMO is an energy of LUMO orbitals, I represents ionization potential, A represents electron affinity, $\chi$ represents electronegativity, $\eta$ represents global hardness, S represents global softness, $\omega$ represents global electrophilicity index and $\mu$ represents electronic chemical potential in the Table 2. The energy value between HOMO and LUMO orbitals is $5.13 \mathrm{eV}(\Delta \mathrm{E})$ as given Table 2. This value is high for the transition of the electron from the HOMO orbital to LUMO orbital. As seen from the Table 2 theobromine is a hard and electronegative molecule.

Table 2. Electronic Parameters of the Theobromine.

\begin{tabular}{cccccccccc}
\hline $\begin{array}{c}\text { Eномо }_{(\mathrm{I})} \\
(\mathrm{eV})\end{array}$ & $\begin{array}{c}\mathrm{E}_{\text {LUmo }} \\
(\mathrm{eV})\end{array}$ & $\begin{array}{c}\Delta \mathrm{E} \\
(\mathrm{eV})\end{array}$ & $\begin{array}{c}\mathrm{I} \\
(\mathrm{eV})\end{array}$ & $\begin{array}{c}\mathrm{A} \\
(\mathrm{eV})\end{array}$ & $\begin{array}{c}\mathrm{X} \\
(\mathrm{eV})\end{array}$ & $\begin{array}{c}\mathrm{H} \\
(\mathrm{eV})\end{array}$ & $\begin{array}{c}\mathrm{s} \\
(\mathrm{eV})\end{array}$ & $\begin{array}{c}\mathrm{M} \\
(\mathrm{eV})\end{array}$ & $\begin{array}{c}\Omega \\
(\mathrm{eV})\end{array}$ \\
\hline-6.04 & -0.91 & 5.13 & 6.04 & 0.91 & 3.48 & 2.57 & 0.39 & -3.48 & 2.35 \\
\hline
\end{tabular}




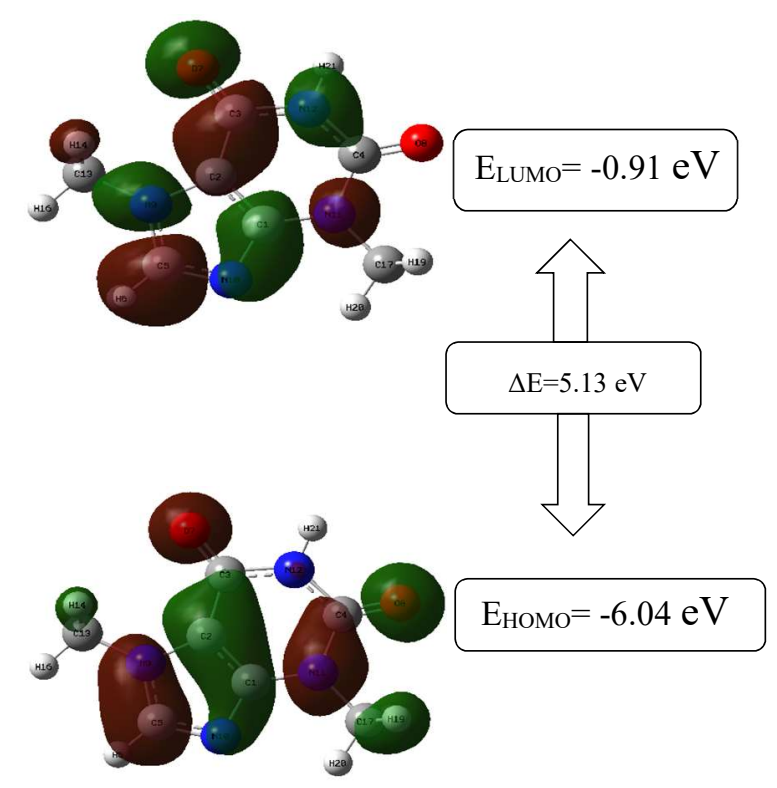

Figure 4. The atomic orbital compositions of the Theobromine.

\section{CONCLUSION}

In this paper, antioxidant and electronic properties of theobromine depending on the temperature were investigated theoretically using density functional theory calculations based on a B3LYP and 6-31G(d,p) basis set quality. Our calculations represented that theobromine showed best antioxidant activity in the $263 \mathrm{~K}$ since the bond dissociation enthalpy and adiabatic ionization potential values are lower in that temperature. However, the electronic properties of the theobromine didn't vary depending on temperature. Antioxidant parameters of the theobromine molecule presented that molecule prefer SET-PT reaction instead of SPLET. The energy difference between HOMO and LUMO orbitals of the theobromine is $5.13 \mathrm{eV}$. This large value is pointed out the proof of the poor probability of the charge transfer in the molecule and also the theobromine is a soft molecule. As a result, methods used in this article can applied to a variety of biomolecules and can enhance our understanding biomaterials nature and are shed light on how we will use such molecules.

\section{Acknowledgement}

The authors are grateful to Pamukkale University (Grant no: 2018FEBE002) and TUBITAK ULAKBIM, High Performance and Grid Computing Center (TRUBA Resources).

\section{Orcid}

Asl1 Öztürk Kiraz (iD) https://orcid.org/0000-0001-9837-0779

\section{REFERENCES}

[1] Martínez-Pinilla E., Oñatibia-Astibia A., Franco R. (2015). The relevance of theobromine for the beneficial effects of cocoa consumption. Front. Pharmacol., 6, 30. DOI:10.3389/fphar.2015.00030.

[2] Mitchell, E. S., Slettenaar, M.,V dMeer, N., Transler, C., Jans, L., Quadt, F., Berry, M. (2011). Differential contributions of theobromine and caffeine on mood, psychomotor performance and blood pressure. Physiol. Behav., 104, 816 - 822. DOI:10.1016/j.physbeh .2011 .07 .027

[3] Baggott, M. J., Childs, E., Hart, A. B., De Bruin, E., Palmer, A.A., Wilkinson, J. E., de Wit, H. (2013). Psycho pharmacology of theobromine in healthy volunteers. Psychopharmacology (Berl), 228, 109-118. DOI:10.1007/s00213-013-3021-0 
[4] van den Bogaard,B., Draijer, R.,Westerhof, B.E.,VanDenMeiracker,A.H., VanMontfrans, G.A.,and Van Den Born, B.J. (2010). Effects on peripheral and central blood pressure of cocoa with natural or high-dose theobromine: a randomized, double-blind crossovertrial. Hypertension, 56, 839-846. DOI: 10.1161/HYPERTENSIONAHA.110.158139

[5] Lemanska, K., Szymusiak, H., Tyrakowska, B., Zielinski, R., Soffers, A.E., Rietjens, I.M. (2001). The influence of $\mathrm{pH}$ on antioxidant properties and the mechanism of antioxidant action of hydroxyflavones. Free Radic. Biol. Med., 31, 869-881. DOI:10.1016/S08915849(01)00638-4

[6] Priyadarsini, K.I., Maity, D.K., Naik, G.H., Kumar, M.S., Unnikrishnan, M.K., Satav, J.G., Mohan, H. (2003). Role of phenolic O-H and methylene hydrogen on the free radical reactions and antioxidant activity of curcumin. Free Radic. Biol. Med., 35, 475-484. DOI:10.1016/S0891-5849(03)00325-3

[7] Kozlowski, D., Marsal, P., Steel, M., Mokrini, R., Duroux, J.-L., Lazzaroni, R., Trouillas, P. (2007). Theoretical investigation of the formation of a new series of antioxidant depsides from the radiolysis of flavonoid compounds. Radiat. Res., 168, 243-252. DOI:10.1667/RR0824.1

[8] Kozlowski, D., Trouillas, P., Calliste, C., Marsal, P., Lazzaroni, R., Duroux, J.-L. (2007). Density functional theory study of the conformational, electronic, and antioxidant properties of natural chalcones. J. Phys. Chem. A, 111, 1138 - 1145. DOI: 10.1021/jp066 $496+$

[9] Anouar, E., Calliste, C.A., Kosinova, P., di Meo, F., Duroux, J.L., Champavier, Y., Marakchi, K., Trouillas, P. (2009). Free radical scavenging properties of guaiacol oligomers: A combined experimental and quantum study of the guaiacyl-moiety role. $J$. Phys. Chem. A, 113, 13881-13891. DOI: 10.1021/jp906285b

[10] Trouillas, P., Marsal, P., Siri, D., Lazzaroni, R., Duroux, J.-L. (2006) A DFT study of the reactivity of $\mathrm{OH}$ groups in quercetin and taxifolin antioxidants: The specificity of the 3OH site. Food Chem., 97, 679-688. DOI:10.1016/j.foodchem.2005.05.042

[11] Trouillas, P., Marsal, P., Svobodova, A., Vostalova, J., Gazak, R., Hrbac, J., Sedmera, P., Kren, V., Lazzaroni, R., Duroux, J.-L., et al. (2008). Mechanism of the Antioxidant Action of Silybin and 2,3-Dehydrosilybin Flavonolignans: A Joint Experimental and Theoretical Study. J. Phys. Chem. A, 112, 1054-1063. DOI:10.1021/jp075814h

[12] Mayer, J.M., Hrovat, D.A., Thomas, J.L., Borden, W.T. (2002). Proton-coupled electron transfer versus hydrogen atom transfer in benzyl/toluene, methoxyl/methanol, and phenoxyl/phenol self- exchange reactions. J. Am. Chem. Soc., 124, 11142 - 11147. DOI: $10.1021 / \mathrm{ja0} 12732 \mathrm{c}$

[13] Wang, L.-F., Zhang, H.-Y. (2004). Unexpected role of 5-OH in DPPH radical-scavenging activity of 4-thiaflavans. Revealed by theoretical calculations. Bioorg. Med. Chem. Lett., 14, 2609-2611. DOI:10.1016/j.bmcl.2004.02.066

[14] Luzhkov, V.B. (2005). Mechanisms of antioxidant activity: The DFT study of hydrogen abstraction from phenol and toluene by the hydroperoxyl radical. Chem. Phys., 314, $211-$ 217. DOI:10.1016/j.chemphys.2005.03.001

[15] Szeląg, M., Mikulski, D., Molski, M. (2011). Quantum - chemical investigation of the structure and the antioxidant properties of $\alpha$-lipoic acid and its metabolites. J. Mol. Mod., 18, 2907-2916. DOI: 10.1007/s00894-011-1306-y

[16] Leopoldini, M., Russo, N., Toscano, M. (2011). The molecular basis of working mechanism of natural polyphenolic antioxidants. Food Chemistry, 125, 288-306. DOI:10.1016/j.foodchem.2010.08.012

[17] Foti, M.C., Daquino, C., Geraci, C. (2004). Electron - transfer reaction of cinnamic acids and their methyl esters with the DPPH radical in alcoholic solutions. J. Org. Chem., 69, 2309-2314. DOI: $10.1021 /$ jo035758q 
[18] Litwinienko, G., Ingold, K.U. (2004). Abnormal solvent effects on hydrogen atom abstraction. 2. Resolution of the curcumin antioxidant controversy. The role of sequential proton loss electron transfer. J. Org. Chem., 69, 5888-5896. DOI: 10.1021/jo049254j

[19] Musialik, M., Litwinienko, G. (2005). Scavenging of dpph. radicals by vitamin E is accelerated by its partial ionization: the role of sequential proton loss electron transfer. Org. Lett., 7, 4951-4954. DOI: 10.1021/o1051962j

[20] Nakanishi, I., Kawashima, T., Ohkubo, K., Kanazawa, H., Inami, K., Mochizuki, M., Fukuhara, K., Okuda, H., . Ozawa, T., Itoh, S., Fukuzumi, S., Ikota, N. (2005). Electron - transfer mechanism in radical scavenging reactions by vitamin $\mathrm{E}$ model in a protic medium. Org. \& Biomolecular Chem., 3, 626-629. DOI: 10.1039/B416572A

[21] Litwinienko, G., Ingold, K.U. (2007). Solvent effects on the rates and mechanisms of reaction of phenols with free radicals. Acc. Chem. Res., 40, 222-230. DOI: 10.1021/ar0682029

[22] Leopoldini, M., Russo, N. Toscano, M. (2006). Gas and Liquid Phase Acidity of Natural Antioxidants. J. Agric. Food Chem,. 54, 3078-3085. DOI: 10.1021/jf053180a

[23] Mikulski, D., Szeląg, M., Molski, M., Górniak, R. (2010). Quantum- chemical study on the antioxidation mechanisms of trans- resveratrol reactions with free radicals in the gas phase, water and ethanol environment. J. Mol. Struct., 951, 37-48. DOI:10.1016/j.theochem.2010.04.005

[24] Sebastian, S., Sundaraganesan, N., Manoharan, S. (2009). Molecular structure, spectroscopic studies and first-order molecular hyperpolarizabilities of ferulic acid by density functional study. Spectrochimica Acta Part A: Molecular and Bio molecular Spectroscopy, 74, 312-323. DOI:10.1016/j.saa.2009.06.011

[25] M. J. Frisch, G. W. Trucks, H. B. Schlegel, G. E. Scuseria, M. A. Robb, J. R. Cheeseman, G. Scalmani, V. Barone, B. Mennucci, G. A. Petersson, H. Nakatsuji, M. Caricato, X. Li, H. P. Hratchian, A. F. Izmaylov, J. Bloino, G. Zheng, J. L. Sonnenberg, M. Hada, M. Ehara, K. Toyota, R. Fukuda, J. Hasegawa, M. Ishida, T. Nakajima, Y. Honda, O. Kitao, H. Nakai, T. Vreven, J. A. Montgomery, Jr., J. E. Peralta, F. Ogliaro, M. Bearpark, J. J. Heyd, E. Brothers, K. N. Kudin, V. N. Staroverov, T. Keith, R. Kobayashi, J. Normand, K. Raghavachari, A. Rendell, J. C. Burant, S. S. Iyengar, J. Tomasi, M. Cossi, N. Rega, J. M. Millam, M. Klene, J. E. Knox, J. B. Cross, V. Bakken, C. Adamo, J. Jaramillo, R. Gomperts, R. E. Stratmann, O. Yazyev, A. J. Austin, R. Cammi, C. Pomelli, J. W. Ochterski, R. L. Martin, K. Morokuma, V. G. Zakrzewski, G. A. Voth, P. Salvador, J. J. Dannenberg, S. Dapprich, A. D. Daniels, O. Farkas, J. B. Foresman, J. V. Ortiz, J. Cioslowski, and D. J. Fox, (2016). Gaussian 09, Revision C.01. Gaussian, Inc., Wallingford CT, 2016.

[26] Roy, D. Dennington II, Todd, A. (2016). GaussView 5, Keith and John M. Millam Copyright Semichem, Inc. 2000-2016.

[27] Diwaker and Abhishek Kumar Gupta, "Quantum Chemical and Spectroscopic Investigations of (Ethyl 4 hydroxy-3-((E)-(pyren-1-ylimino)methyl)benzoate) by DFT Method," International Journal of Spectroscopy, vol. 2014, Article ID 841593, 15 pages, 2014. DOI:10.1155/2014/841593

[28] Kara, I., Kara,Y., Öztürk Kiraz, A., Mammadov, R. (2015). Theoretical calculations of a compound formed by $\mathrm{Fe}^{+3}$ and tris(catechol) Spectrochimica Acta Part A: Molecular and Biomolecular Spectroscopy, 149, 592-599. DOI:10.1016/j.saa.2015.04.058. 